\title{
C-Reactive Protein and Respiratory Viral Infection
}

\author{
Jae-Sik Jeon ${ }^{1}$, Insoo Rheem ${ }^{1}$, Jae Kyung Kim ${ }^{2}$ \\ ${ }^{1}$ Department of Laboratory Medicine, Dankook University College of Medicine, Cheonan, Korea \\ ${ }^{2}$ Department of Biomedical Laboratory Science, Dankook University College of Health Sciences, Cheonan, Korea
}

\section{호흡기 바이러스 감염과 C-Reactive Protein}

\author{
전재식 ${ }^{1}$, 임인수 $^{1}$, 김재경 $^{2}$ \\ ${ }^{1}$ 단국대학교 의과대학 임상병리학과, ${ }^{2}$ 단국대학교 보건과학대학 임상병리학과
}

\begin{abstract}
C-reactive protein (CRP) levels are not generally associated with viral infections. This study investigated the changes in the CRP level caused by an infection from respiratory virus (RV). Nasopharyngeal samples from hospitalized patients with suspected RV infection were used to measure the CRP levels, virus load, virus-virus co-infection, age, sex, and length of hospital stay (LOS). Abnormal CRP levels were detected in 62.3\% (3,608 out of 5,788) of all RV-positive samples. The percentage of patients with abnormal CRP levels tended to increase with age. Furthermore, LOS in patients with abnormal CRP levels was significantly longer than that in patients with normal CRP levels. The frequency of elevated CRP levels differed according to the causative virus and the frequency of abnormal levels increased with age. Moreover, LOS was longer in those with abnormal CRP levels. These data provide important insights into the role of CRP levels in RV infection.
\end{abstract}

Key words: Coinfection, C-Reactive Protein, Length of stay, Respiratory virus, Virus diseases

This is an Open Access article distributed under the terms of the Creative Commons Attribution Non-Commercial License (http://creativecommons.org/licenses/by-nc/4.0) which permits unrestricted non-commercial use, distribution, and reproduction in any medium, provided the original work is properly cited.

Copyright @ 2017 The Korean Society for Clinical Laboratory Science. All rights reserved.
Corresponding author: Jae Kyung Kim

Department of Biomedical Laboratory Science, Dankook University College of Health Sciences, 119 Dandae-ro, Dongnan-gu, Cheonan 31116 , Korea

Tel: 82-41-550-1451

Fax: 82-41-559-7934

E-mail: nerowolf2@dankook.ac.kr

Received: January 1, 2017

Revised $1^{\text {st. }}$ : February 14, 2017

Revised 2nd: February 22, 2017

Revised $3^{\text {rd: }}$ : February 24, 2017

Accepted: February 24, 2017

\section{INTRODUCTION}

Respiratory virus (RV) infection is the most common disease in humans, accounting for approximately $50 \%$ of all diseases [1]. Additionally, RV is one of the most contagious communicable pathogens and can rapidly infect a large number of individuals [2]. Because different RVs cause similar symptoms and signs, it is difficult to differentiate the causative virus solely based on clinical features [2-5].

However, recent developments in molecular biology-based diagnostic techniques for identification of viruses, such as sequencing or multiplex reverse trans- cription polymerase chain reaction, have facilitated simultaneous examination of a number of respiratory viruses, allowing simple, accurate extraction of the causative virus.

As such, much effort has been focused on effective treatment and prevention of RV infection by improving our understanding of the symptoms and clinical features of infected individuals based on the causative RV; this has been done to prevent antibiotic abuse and the spread of the disease [6]. Various studies have reported haematological characteristics, including abnormal elevation or reduction in the number of haemoglobin molecules or platelets, 
based on the causative virus $[7,8]$. For example, it was observed that patients with RSV pneumonia were more co-infected by bacteria than those with RSV bronchiolitis and bronchopneumonia, so that patients with RSV pneumonia had elevated levels of WBC count, CRP and erythrocyte sedimentation rate (ESR) than those with bronchiolitis or bronchopneumonia [9]. Among these proteins, $\mathrm{CRP}$ is the most representative of acute phase reactants $[10,11]$. Although elevated CRP levels indicate bacterial infection [12], it was reported to be still insufficient to conclude as direct evidence that virus causes elevation of CRP levels [13]. However, infection of RV such as RSV is prone to co-infection with other bacteria or viruses, and CRP level increases together [9], so that identification of levels of biomarker proteins such as CRP can be an important indirect indication for viral infection. However, similar levels may be observed in patients with inflammatory diseases or in those infected with certain viral strains (e.g., adenovirus and influenza) $[14,15]$.

In comparison to adults, children are more susceptible to viruses or bacteria, and show more cold-related symptoms accompanied by fever or coughing that are caused by these sources of infection. In case of these symptoms, various tests and studies have been performed to identify the cause. Although biomarkers are not recommended in primary examination to identify presence of pathogens [16,17], CRP can be used as a biomarker for inflammation, which enables to trace progress of infection or monitor treatment effect, so that studies on various sources of infection and CRP have been actively conducted to date. Nevertheless, RV and CRP have been relatively unexplored. Infection by RV can cause various symptoms accompanied by fever, and secondary infection to subjects with declined immunity causes many complications during viral prevailing season, even resulting in death sometimes. As such, it is highly critical to find biomarkers to diagnose specific viruses.

Although a recent study showed that CRP may be used to detect various viruses in the clinical setting [18], studies applying CRP levels for diagnosis of RV infections are lacking. Therefore, in this retrospective study, we compared and analysed the correlations between RV infection and CRP levels. We examined 12 types of RVs (Table 1) and the associations of these RVs with CRP levels, while considering patient age, sex, and length of hospital stay (LOS), to investigate the characteristics of each virus. In addition, while considering various factors such as gender and age, changes in CRP level are compared when infected by RV, by which it is expected that this study can investigate close relationships of CRP level with specific RVs.

\section{MATERIALS AND METHODS}

The present study was approved by the institutional review board (IRB) of Dankook University (Date of IRB approval: 2015.10.13; IRB approval No.: 2015-09-009).

\section{Subject and sample collection}

A total of 9,204 patients admitted at Dankook University Hospital for respiratory symptoms between December 2006 and February 2014 were included in this study. Patients were admitted via the emergency room with symptoms of acute respiratory illness or via outpatient services. General blood tests and tests examining for the

Table 1. Material and diagnostic method

Details

Virus type

human adenovirus [hADV]; human coronavirus [hCoV] 229E/NL63, and OC43; human metapneumovirus [hMPV]; human rhinovirus [hRV]; influenza virus [INF] A and B; parainfluenza virus [PIV] types 1,2 and 3; and respiratory syncytial virus [RSV] $A$ and $B$

Diagnostic method (RT-PCR) PTC 200 PCR system (MJ Research, Watertown, MA, USA) with a program of 40 cycles of: $30 \mathrm{~s}$ at $94^{\circ} \mathrm{C}$, $90 \mathrm{~s}$ at $60^{\circ} \mathrm{C}$, and $90 \mathrm{~s}$ at $72^{\circ} \mathrm{C}$, followed by 1 cycle of $10 \mathrm{~min}$ at $72^{\circ} \mathrm{C}$

Diagnostic method (CRP)

Type of diagnostic kit

Material

MODULAR P auto-analyser with specialized reagents (Roche Diagnostics, Mannheim, Germany) Seeplex RV detection kit-1 (Seegene, Seoul, Korea)

A total of 9,204 patients blood sample treated at Dankook University Hospital for respiratory symptoms 
presence of RV were performed on all patients. Within 24 hours of admission, nasopharyngeal fluids were collected by inserting a mucus extractor connected to a sterile 8-French catheter $5 \sim 7 \mathrm{~cm}$ into the nostril and suctioning with a pressure of $60 \sim 80 \mathrm{mmHg}$. Samples were stored at $4^{\circ} \mathrm{C}$ until nucleic acid extraction was performed. The extracted nucleic acids were stored at $-70^{\circ} \mathrm{C}$ until the tests were performed.

\section{Analysis of CRP levels}

Blood samples were drawn for CRP analysis. Sera were stored at $-20^{\circ} \mathrm{C}$ until use. CRP levels were measured using particle-enhanced immunoturbidimetric assays using a MODULAR P auto-analyser with specialized reagents (Roche Diagnostics, Mannheim, Germany). CRP samples were also analysed by means of an immunoturbidimetric method using an analyser and reagents from the same manufacturer. A CRP level of $0.5 \mathrm{mg} / \mathrm{dL}$ or higher was considered abnormal.

\section{Extraction of RV nucleic acids and RV detection}

Nucleic acid extraction was performed using a QIAamp DNA Mini Kit (Qiagen, Hilden, Germany) according to the manufacturer's protocol with a QIAcube instrument (Qiagen). RNA was isolated from nasopharyngeal fluid and reconstructed as complementary deoxyribonucleic acid (cDNA). The cDNA was then amplified using a Seeplex RV detection kit-1 (Seegene, Seoul, Korea) to test for one DNA virus (human adenovirus [hADV]) and 11 RNA viruses that cause respiratory infection (human coronavirus [hCoV] 229E/NL63, and OC43; human metapneumovirus [hMPV]; human rhinovirus [hRV]; influenza virus [INF] A and B; parainfluenza virus [PIV] types 1, 2 and 3; and respiratory syncytial virus [RSV] A and B) PCR was performed using the PTC 200 PCR system (MJ Research, Watertown, MA, USA), and the following program was implemented: 40 cycles of $30 \mathrm{~s}$ at $94^{\circ} \mathrm{C}, 90 \mathrm{~s}$ at $60^{\circ} \mathrm{C}$, and $90 \mathrm{~s}$ at $72^{\circ} \mathrm{C}$, followed by one cycle of $10 \mathrm{~min}$ at $72^{\circ} \mathrm{C}$. The amplified PCR products were analysed following $30 \mathrm{~min}$ of

Table 2. Analysis of cases, positive rates and infection types

\begin{tabular}{|c|c|c|c|c|c|}
\hline & \multirow{2}{*}{ No. of samples } & \multicolumn{2}{|c|}{ Age (years) } & \multirow{2}{*}{ Ratio } & \multirow{2}{*}{$\begin{array}{l}\text { Average CRP } \\
(\mathrm{mg} / \mathrm{dL})\end{array}$} \\
\hline & & Average & Median & & \\
\hline Submitted & 9,205 & 14.1 & 2.0 & $100.0 \%$ & \\
\hline Positive & 5,788 & 7.6 & 1.4 & $62.9 \%$ & 2.80 \\
\hline Male & 3,394 & 7.9 & 1.4 & $36.9 \%$ & 2.83 \\
\hline Female & 2,394 & 7.3 & 1.6 & $26.0 \%$ & 2.76 \\
\hline Sex ratio $(M / F)$ & $1.41: 1$ & & & & \\
\hline Negative & 3,417 & 25.1 & 5.6 & $37.1 \%$ & 5.25 \\
\hline Single & 4,610 & 8.5 & 1.4 & $50.1 \%$ & 2.82 \\
\hline Multiple & 1,178 & 4.2 & 1.5 & $12.8 \%$ & 2.76 \\
\hline Double & 1,053 & 4.1 & 1.5 & $11.4 \%$ & 2.71 \\
\hline Triple or more & 125 & 4.4 & 1.6 & $1.4 \%$ & 3.17 \\
\hline Virus & 7,096 & 7.6 & 1.4 & $100.0 \%$ & 2.80 \\
\hline hADV & 1,085 & 5.0 & 2.2 & $15.3 \%$ & 3.66 \\
\hline hCoV 229E/NL63 & 205 & 12.2 & 1.8 & $2.9 \%$ & 3.80 \\
\hline hCoV OC 43 & 226 & 10.4 & 1.6 & $3.2 \%$ & 4.19 \\
\hline hMPV & 497 & 8.7 & 1.8 & $7.0 \%$ & 3.48 \\
\hline hRV & 1,529 & 5.0 & 1.5 & $21.6 \%$ & 2.61 \\
\hline INF A & 602 & 19.2 & 5.0 & $8.5 \%$ & 4.08 \\
\hline INF B & 170 & 17.7 & 5.3 & $2.4 \%$ & 3.51 \\
\hline PIV 1 & 266 & 5.0 & 1.5 & $3.7 \%$ & 2.12 \\
\hline PIV 2 & 85 & 5.0 & 2.1 & $1.2 \%$ & 2.44 \\
\hline PIV 3 & 478 & 6.0 & 1.2 & $6.7 \%$ & 2.36 \\
\hline RSV A & 1,106 & 3.3 & 0.5 & $15.6 \%$ & 1.67 \\
\hline RSV B & 847 & 5.3 & 0.8 & $11.9 \%$ & 1.95 \\
\hline
\end{tabular}

Abbreviation: hADV, human adenovirus; hCoV, human coronavirus; hMPV, human metapneumovirus; hRV, human rhinovirus; INF, influenza; PIV, parainfluenza virus; RSV, respiratory syncytial virus. 
electrophoresis at 100 150 V in 2\% agarose gels stained with ethidium bromide.

\section{Statistical analysis}

RV PCR and CRP levels were evaluated to analyse patterns and differences in CRP levels in relation to multiple infections, causative viruses, sex, and age. Regression analysis and Welch's $t$-tests were performed. A $p$ value of less than 0.05 was considered statistically significant.

\section{RESULTS}

\section{Patient characteristics}

Of the 9,205 cases included in this study, 5,788 (62.9\%; 3,394 men and 2,394 women) patients tested positive for RV. The average age of RV-positive patients was 7.6 years, and the median age was 1.4 years. A total of 7,096 strains were detected in all samples and rhinovirus was the most frequently detected virus (1,529 cases; $21.5 \%)$, followed by RSV A ( 1,106 cases; $15.6 \%)$ and hADV (1,085 cases; $15.3 \%$; Table 2).

\section{Analysis of viral infection and CRP levels}

In RV-positive cases, the rate of abnormal CRP levels was $62.8 \%$ (3,633 of 5,788 cases). In cases of single RV infection, the rate of abnormal CRP levels was $61.9 \%$ (2,855 of 4,610 cases), whereas in cases of viral co-infection (two or more infections), the rate of abnormal CRP levels was

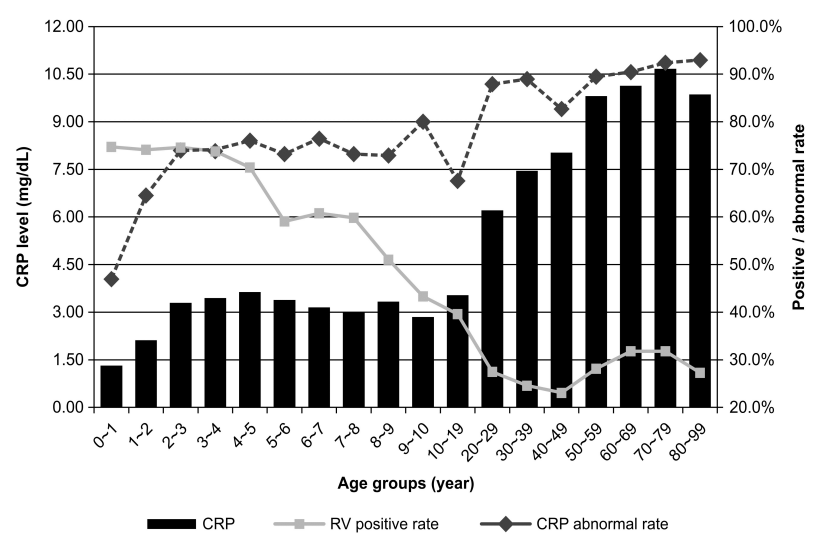

Figure 1. Rate of abnormal CRP levels in each age group. The solid line indicates the RV-positive rate, and the broken line indicates the CRP abnormal rate. Abbreviation: CRP, C-reactive protein; RV, respiratory virus.
66.0\% (778 of 1,178 cases). Abnormal CRP levels were observed in $66.0 \%$ (695 of 1,053 cases) of double-infection cases and in $66.4 \%$ ( 83 of 125 cases) of $\geq$ triple-infection cases (Table 2).

The differences in abnormal CRP rates between overall positive cases and cases of co-infection were not statistically significant $(p=0.28$ ), and no significant differences were observed between single infection and $\geq$ double infections ( $p=0.48$ and $p=0.37$, respectively). The average CRP levels were $2.80 \pm 4.87 \mathrm{mg} / \mathrm{dL}$ in all RV-positive patients, $2.82 \pm 4.94 \mathrm{mg} / \mathrm{dL}$ in patients with single infections, and $2.71 \pm 4.56 \mathrm{mg} / \mathrm{dL}$ in patients with double infections.

Of the RV-positive patients, those in the group aged 70 79 years had the highest rate of abnormal CRP levels and the highest levels of CRP (10.67 mg/dL; Figure 1). Regression analysis showed that CRP levels tended to increase with age ( $p<0.001$; Figure 2). Moreover, $67.6 \%$ of teenagers and $94.2 \%$ of individual aged $70 \sim 79$ years exhibited abnormal CRP levels (Table 3).

The rate of abnormal CRP levels was highest in patients infected with hADV (79.2\%) and lowest in patients infected with RSV A (47.2\%). Based on virus type, the average CRP

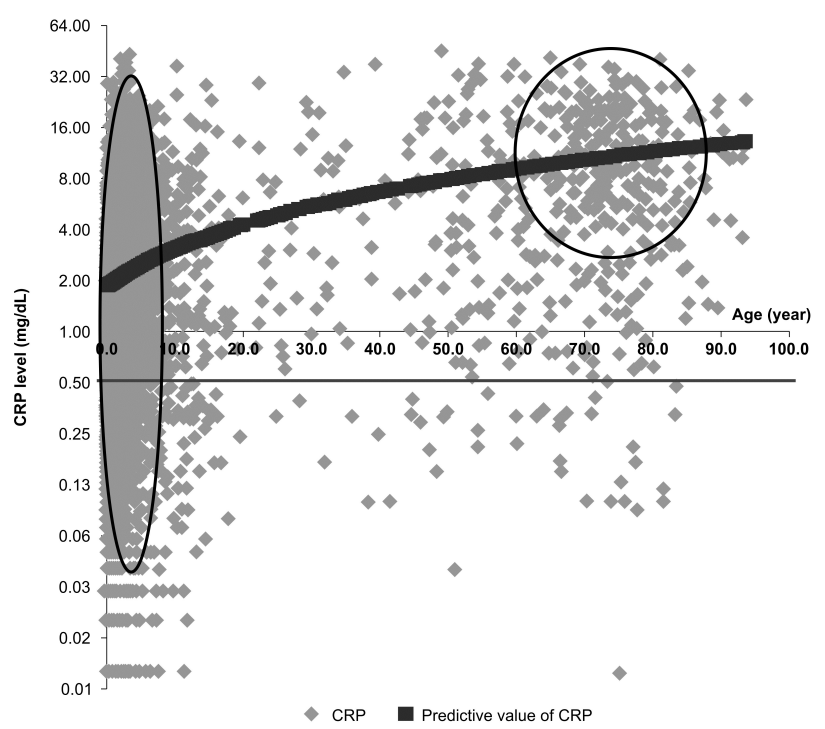

Figure 2. Distribution of CRP levels according to age in the RV-positive patients. The vertical axis reflects the CRP level(mg/dl) and horizontal axis was divided by dividing each age into 10 years. The line parallel to the horizontal axis (CRP level 0.5) indicate the normal value. The gray squares $(\bullet)$ and black squares $(\boldsymbol{\square})$, respectively, indicate CRP and predictive value of CRP. The two circles indicate the area where the distribution of CRP is concentrated. 
Table 3. Distribution of CRP levels by age in respiratory virus infection patients

\begin{tabular}{ccccc}
\hline Age group (years) & Positivespecimens & Average CRPlevel (mg/dL) & CRP Abnormal count & CRP Abnormal rate \\
\hline $0 \sim 9$ & 5,136 & 2.10 & 3,069 & $59.8 \%$ \\
$10 \sim 19$ & 143 & 3.53 & 96 & $67.1 \%$ \\
$20 \sim 29$ & 25 & 6.20 & 23 & $92.0 \%$ \\
$30 \sim 39$ & 29 & 7.46 & 25 & $86.2 \%$ \\
$40 \sim 49$ & 36 & 8.02 & 28 & $77.8 \%$ \\
$50 \sim 59$ & 72 & 9.81 & 67 & $93.1 \%$ \\
$60 \sim 69$ & 110 & 10.14 & 102 & $92.7 \%$ \\
$70 \sim 79$ & 171 & 10.67 & 161 & $94.2 \%$ \\
$80 \sim 89$ & 57 & 9.76 & 53 & $93.0 \%$ \\
$90 \sim 99$ & 9 & 10.52 & 9 & $100.0 \%$ \\
Total & 5,788 & & 3,633 & \\
\hline
\end{tabular}

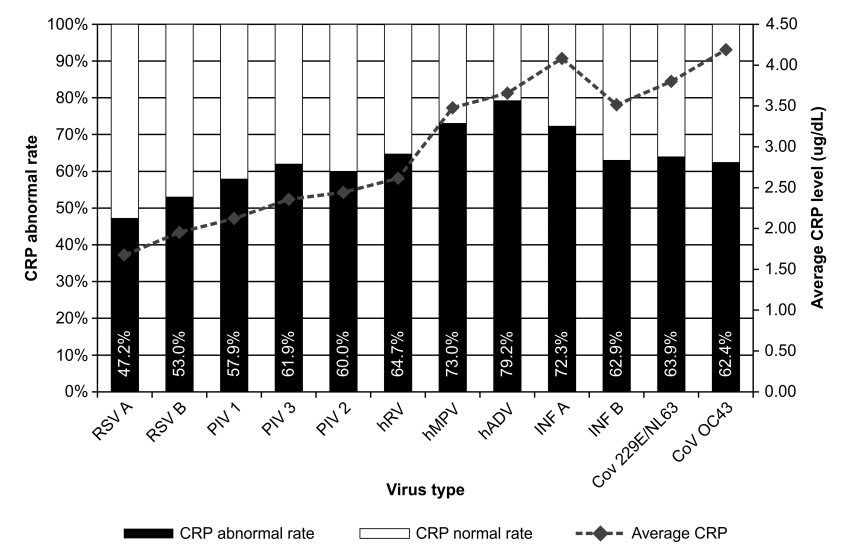

Figure 3. Rate of abnormal CRP levels according to causative virus.

level was the highest in those infected with hCoV OC43 $(4.19 \pm 7.22 \mathrm{mg} / \mathrm{dL} ; p=0.004)$ and the lowest in those infected with RSV A $(1.67 \pm 3.75 \mathrm{mg} / \mathrm{dL}$; Figure 3).

\section{DISCUSSION}

Viral infections can cause various abnormalities, including variations in CRP levels and platelet counts, which are the result of autoimmune responses and suppression of bone marrow progenitors [19]. In particular, CRP levels reflect the severity of the acute phase reaction [20]. Substantially increased CRP values are usually found in patients with pneumonia, and high CRP levels have been shown to be a strong predictor for disease in general practice [21].

The RV positivity rate was approximately $62.9 \%$, which is similar to the results of Kim et al [1]. Moreover, the highest positive rate was in patients younger than 10 years of age, consistent with previous studies [1,3,22]. Our findings were also consistent with other reports in terms of the most commonly identified viruses (i.e., HRV and RSV A) $[1,22]$. We found that $62.8 \%$ of RV-positive patients had abnormal CRP levels, similar to the range (68 85\%) reported in RV-infected patients in previous studies [23,24]. In contrast with the findings of some previous studies [25-27], co-infections in the current study were not more severe than single infections [28-30]. In addition, consistent with our study, a study by Guo et al [31]. showed a gradual increase in CRP levels with age.

The increased severity of viral infections has recently been reported to prolong LOS [32]. Abnormal CRP levels in the present study were associated with longer LOS. As such, increased CRP levels may be used as a predictive factor for hospitalization in the intensive care unit or the requirement for mechanical ventilation [33]. Furthermore, our data provide evidence for differentiating between high- and low-risk patients, which has clear-cut clinical and therapeutic implications for decision-making on issues of patient management [34].

There were not significant increases in CRP levels during RV infection including co-infection by multiple viruses. However, when RVs were analysed individually, a significant increase in CRP level was observed during specific RV infections, with more prominent increases observed in elderly patients. Additionally, based on the higher proportion of elderly individuals with high CRP levels, in-depth studies on the biochemical and immunological relationships of different types of RVs in this 
particular patient subset will be needed. Furthermore, to promote the timely diagnosis and treatment of patients, CRP tests should be carried out concurrently with virus identification tests.

\section{Acknowledgements: None \\ Funding: None \\ Conflict of interest: None}

\section{REFERENCES}

1. Kim JK, Jeon JS, Kim JW, Rheem I. Epidemiology of respiratory viral infection using multiplex RT-PCR in Cheonan, Korea (2006-2010). J Microbiol Biotechnol. 2013;23(2):267-273.

2. Mäkelä MJ, Puhakka T, Ruuskanen O, Leinonen M, Saikku P, Kimpimäki M, et al. Viruses and bacteria in the etiology of the common cold. J Clin Microbiol. 1998;36(2):539-542.

3. Kim SH, Huh JH, Bae SY, Kim JS, Yoon SY, Lim CS, et al. Epidemiology of respiratory viral infection in 2004-2006. Korean J Lab Med. 2006;26(5):351-357.

4. Nichols WG, Peck Campbell AJ, Boeckh M. Respiratory viruses other than influenza virus: impact and therapeutic advances. Clin Microbiol Rev. 2008;21(2):274-290.

5. Cho KS. Characterization and outbreak pattern of influenzavirus isolated in Busan Area, 2000-2002 years. Korean J Clin Lab Sci. 2003;35(1):1-8.

6. Choi EH, Lee HJ, Kim SJ, Eun BW, Kim NH, Lee JA, et al. The association of newly identified respiratory viruses with lower respiratory tract infections in Korean children, 2000-2005. Clin Infect Dis. 2006;43(5):585-592.

7. Bilavsky E, Yarden-Bilavsky H, Shouval DS, Fisch N, Garty BZ, Ashkenazi S, et al. Respiratory syncytial virus-positive bronchiolitis in hospitalized infants is associated with thrombocytosis. Isr Med Assoc J. 2010;12(1):39-41.

8. Park IH, Lee SH, You ST, Choi DY. Hematologic complication of respiratory virus infection. Korean J Pediatr Infect Dis. 2013; 20(3):178-185.

9. Saijo M, Ishii T, Kokubo M, Murono K, Takimoto M, Fujita K. White blood cell count, C-reactive protein and erythrocyte sedimentation rate in respiratory syncytial virus infection of the lower respiratory tract. Acta Paediatr Jpn. 1996;38(6):596-600.

10. Hur M, Lee YK, Kang HJ, Lee KM. Distribution of high-sensitivity C-reactive protein in Korean healthy individuals. J Clin Pathol Qual Control. 2001;23(2):259-263.

11. Lee CK, Ryu JR, Nam HC, Park JS, Whang SJ, Jung SK, et al. ROC analysis of CRP assay among some acute chest pain patients. Korean J Clin Lab Sci. 2000;32(3):162-168.

12. Woodhead M, Blasi F, Ewig S, Garau J, Huchon G, Ieven M, et al. Guidelines for the management of adult lower respiratory tract infections - full version. Clin Microbiol Infect. 2011;17(6):E1-59.

13. van der Meer V, Neven AK, van den Broek PJ, Assendelft WJ. Diagnostic value of $C$ reactive protein in infections of the lower respiratory tract: systematic review. BMJ. 2005;331:26. doi:
10.1136/bmj.38483.478183.EB.

14. Appenzeller C, Ammann RA, Duppenthaler A, Gorgievski-Hrisoho M, Aebi C. Serum C-reactive protein in children with adenovirus infection. Swiss Med Wkly. 2002;132(25-26):345-350.

15. Oved K, Cohen A, Boico O, Navon R, Friedman T, Etshtein L, et al. A novel host-proteome signature for distinguishing between acute bacterial and viral infections. PLoS One. 2015;10(3): e0120012.

16. Graffelman AW, Knuistingh NA, le CS, Kroes AC, Springer MP, van den Broek PJ. A diagnostic rule for the aetiology of lower respiratory tract infections as guidance for antimicrobial treatment. Br J Gen Pract. 2004; 54:20-24.

17. Holm A, Pedersen SS, Nexoe J, Obel N, Nielsen LP, Koldkjaer O, et al. Procalcitonin versus C-reactive protein for predicting pneumonia in adults with lower respiratory tract infection in primary care. Br J Gen Pract. 2007; 57(540):555-560.

18. Wang Y, Chen Z, Yan YD, Guo H, Chu C, Liu J, et al. Seasonal distribution and epidemiological characteristics of human metapneumovirus infections in pediatric inpatients in Southeast China. Arch Virol. 2013;158:417-424.

19. Peter E. Leukopenia. In: Kliegman RM, Stanton BF, editors. Nelson textbook of pediatrics. 19th ed. Philadelphia: Elsevier Saunders; 2011. p746-752.

20. Korppi M, Heiskanen-Kosma T, Leinonen M. White blood cells, C-reactive protein and erythrocyte sedimentation rate in pneumococcal pneumonia in children. Eur Respir J. 1997;10(5): $1125-1129$.

21. Melbye H, Hvidsten D, Holm A, Nordb ø SA, Brox J. The course of $\mathrm{C}$-reactive protein response in untreated upper respiratory tract infection. Br J Gen Pract. 2004;54(506):653-658.

22. Nunes MC, Kuschner Z, Rabede Z, Madimabe R, Niekerk NV, Moloi J, et al. Clinical epidemiology of bocavirus, rhinovirus, two polyomaviruses and four coronaviruses in HIV-infected and HIV-uninfected South African children. PLoS One. 2014; 9(2):e86448.

23. Kim HK, Ham SC, Nam SY, Koh YJ, Ahn KM, Lee SI. A clinical study of adenoviral respiratory infection in children. Korean J Pediatr. 2000;43(2):195-202.

24. Lee HJ, Jang SH. Clinical and epidemiologic features of respiratory syncytial virus infection. Korean J Pediatr. 1992;35(10): 1389-1401.

25. Aberle JH, Aberle SW, Pracher E, Hutter HP, Kundi M, Popow-Kraupp T. Single versus dual respiratory virus infections in hospitalized infants: impact on clinical course of disease and interferon-gamma response. Pediatr Infect Dis J. 2005;24(7):605-610.

26. Papadopoulos NG, Moustaki M, Tsolia M, Bossios A, Astra E, Prezerakou A, et al. Association of rhinovirus infection with increased disease severity in acute bronchiolitis. Am J Respir Crit Care Med. 2002;165(9):1285-1289.

27. Semple MG, Cowell A, Dove W, Greensill J, McNamara PS, Halfhide $\mathrm{C}$, et al. Dual infection of infants by human metapneumovirus and human respiratory syncytial virus is strongly associated with severe bronchiolitis. J Infect Dis. 2005;191(3): 382-386.

28. Bicer S, Giray T, Çöl D, Erdağ GÇ, Vitrinel A, Gürol Y, et al. Virological and clinical characterizations of respiratory in- 
fections in hospitalized children. Ital J Pediatr. 2013;39:22. doi: 10.1186/1824-7288-39-22.

29. Pierangeli A, Gentile M, Di Marco P, Pagnotti P, Scagnolari C, Trombetti S, et al. Detection and typing by molecular techniques of respiratory viruses in children hospitalized for acute respiratory infection in Rome. Italy J Med Virol. 2007;79(4): 463-468.

30. van Woensel JB, Bos AP, Lutter R, Rossen JW, Schuurman R. Absence of human metapneumovirus co-infection in cases of severe respiratory syncytial virus infection. Pediatr Pulmonol. 2006;41(9):872-874.

31. Guo WL, Wang J, Zhu LY, Hao CL. Differentiation between mycoplasma and viral community-acquired pneumonia in chil- dren with lobe or multi foci infiltration: a retrospective case study. BMJ Open. 2015;5(1):e006766.

32. Kim JK, Jeon JS, Kim JW, Kim GY. Correlation between abnormal platelet count and respiratory viral infection in patients from Cheonan, Korea. J Clin Lab Anal. 2016;30(3):185-189.

33. Zimmerman O, Rogowski O, Aviram G, Mizrahi M, Zeltser D, Justo D, et al. C-reactive protein serum levels as an early predictor of outcome in patients with pandemic H1N1 influenza A virus infection. BMC Infect Dis. 2010;10:288. doi: 10.1186/ 1471-2334-10-288.

34. Putto A, Ruuskanen O, Meurman O, Ekblad H, Korvenranta H, Mertsola J, et al. C reactive protein in the evaluation of febrile illness. Arch Dis Child. 1986;61(1):24-29. 